\title{
Euro-Latin-American Cooperation Against Corruption and its Impact on Human Rights
}

\section{La cooperación Euro-Latinoamericana contra la corrupción y su impacto en los Derechos Humanos}

\author{
Rosana Garciandia ${ }^{1}$ \\ King's College London (Inglaterra)
}

Recibido: 31-05-18

Aprobado: 12-07-18

\begin{abstract}
Under the UN Convention against Corruption (UNCAC), as well as under regional conventions, Latin-American and European States are strengthening their efforts to combat corruption by, among other measures, consolidating their international cooperation. Building on the increasingly acknowledged impact of corruption on human rights, this paper explores how the substantive link between corruption and human rights could be unfolded to develop cooperation strategies against corruption with a positive impact on human rights. It does it using as examples a selection of initiatives of inter-regional cooperation against corruption between Europe and Latin-America.
\end{abstract}

Key-words: Corruption, human rights, Europe, Latin-America, cooperation.

\section{Resumen}

Los países de América Latina y Europa han venido fortaleciendo sus esfuerzos contra la corrupción en el marco de la Convención de las Naciones Unidas contra la Corrupción, así como de instrumentos regionales contra la corrupción, entre otras medidas consolidando la cooperación internacional. Partiendo del creciente reconocimiento del impacto de la corrupción en los derechos humanos,

\footnotetext{
${ }^{1}$ (rosana.garciandia@kcl.ac.uk). Research Associate and Visiting Lecturer at The Dickson Poon School of Law, King's College London and Consultant at the UN Office on Drugs and Crime (UNODC). This paper has been written in a personal capacity and does not necessarily reflect the views of UNODC.
}

Araucaria. Revista Iberoamericana de Filosofia, Politica, Humanidades y Relaciones Internacionales, año 20, ${ }^{\circ} 40$. Segundo semestre de 2018. Pp. 605-629. ISSN 1575-6823 e-ISSN 2340-2199 doi: 10.12795/araucaria.2018.i40.25 
este artículo explora de qué manera la conexión entre corrupción y derechos humanos puede utilizarse para conseguir que las medidas anticorrupción tengan consecuencias positivas en materia de derechos humanos. El análisis que aquí se presenta se apoya para ello en una selección de iniciativas de cooperación contra la corrupción en las que participan países europeos y latinoamericanos.

Palabras-clave: Corrupción, derechos humanos, Europa, América Latina, cooperación.

\section{Introduction}

Europe and Latin-America have developed over decades their own regional integration processes in various areas, including the fight against corruption. Under the UN Convention against Corruption, as well as under regional conventions, Latin-American and European States are strengthening their efforts to combat corruption, although this seems to remain a challenge for many, with many corruption cases reported in the news and investigated and prosecuted by national courts.

Civil society perceives those corruption cases, particularly the ones in the public sector, as a threat to its welfare, as corruption cases commonly involve abuse of power, misappropriation of public funds or misuse of public institutions. Beyond this perception, corruption has a negative impact on human rights. Access to justice or the right to equal treatment can be directly impacted by corruption offences, as may other rights such as the right to food, the right to housing or the right to education.

Building on the increasingly acknowledged impact of corruption on human rights, this paper explores how the substantive link between corruption and human rights could be unfolded to develop cooperation strategies against corruption with positive effects on human rights. It does it using as examples a selection of initiatives of inter-regional cooperation against corruption between Europe and Latin-America.

The paper is structured in two parts. The first part presents the main aspects of the connection between corruption and human rights and identifies, following Resolution 35/25 of the UN Human Rights Council, areas with potential to transform the substantive link between corruption and human rights and use it to define anti-corruption measures with positive effects on human rights. The second part analyses how that potential could turn into positive effects for human rights, focusing on a selection of cooperation initiatives in which European and Latin-American countries take part in connection with their obligations under the UN Convention against Corruption. This paper is limited 
in scope and does not aim at presenting an exhaustive study of all Euro-LatinAmerican anti-corruption cooperation initiatives. It aims at reflecting about the potential of cooperation against corruption as a mechanism that could have positive effects on human rights.

\section{The impact of corruption on human rights}

The inclusion of corruption in the UN 2030 Agenda through targets 16.4 and 16.5 confirms the relevance it has gained in the development agenda and illustrates the general acknowledgement of the negative effect of corruption on development and human rights. ${ }^{2}$ As the UN Human Rights Council recognized in its Resolution $35 / 25$ of $2017,{ }^{3}$ there is an "increasing awareness in the international community of the detrimental impact of widespread corruption on human rights". ${ }^{4}$ According to this resolution, the negative effect that corruption has on human rights manifests mainly through "the weakening of institutions and the erosion of public trust in government, and through the impairment of the ability of Governments to fulfil all their human rights obligations and to realize, within the maximum available resources, the Sustainable Development Goals".5

The effects of corruption on human rights have been analysed thoroughly in the last decade, leading to consider ways in which the anti-corruption and human rights frameworks could benefit from a closer connection. ${ }^{6}$ This section looks at ways in which corruption can affect human rights. It also presents the avenues that the UN Human Rights Council has identified to transform the substantive linkage between corruption and human rights into anti-corruption strategies that may have positive effects on human rights.

${ }^{2}$ Target 16.4 calls States to "significantly reduce illicit financial and arms flows, strengthen the recovery and return of stolen assets and combat all forms of organized crime". Target 16.5 calls them to "substantially reduce corruption and bribery in all their forms".

3 The UN Human Rights Council has dedicated various resolutions to different aspects of the effects of corruption on human rights: the negative impact of corruption on the enjoyment of human rights (resolution 23/9), the role of good governance in the promotion and protection of human rights (resolution 19/20), the negative impact of the non-repatriation of funds of illicit origin to the countries of origin on the enjoyment of human rights, and the importance of improving international cooperation (resolution 22/12). The Human Rights Council also recognized the importance of fighting corruption for the prevention of human rights violations (resolution 18/13).

${ }^{4}$ UN Human Rights Council, Resolution 35/25, The negative impact of corruption on the enjoyment of human rights, adopted on 23 June 2017.

${ }^{5}$ Ibid.

${ }^{6}$ Landman, T., Schudel, C. J. W., Corruption and Human Rights: Empirical Relationships and Policy Advice, International Council on Human Rights Policy, 2007; Kaufmann, D., Human Rights and Governance: The Empirical Challenge, in Human Rights and Development: Towards Mutual Reinforcement, edited by Philip Alston and Mary Robinson, Oxford University Press, 2005; Boersma, M., Corruption: A Violation of Human Rights and a Crime Under International Law, Intersentia, 2012. 


\section{a) How does corruption affect human rights?}

In the last decade, the UN bodies dealing with corruption and human rights, the Human Rights Council and Commission and the UN Office on Drugs and Crime (UNODC), have explored the connection between corruption and human rights, given the "need for an increased recognition and analysis of how corruption contributes to the violation of human rights and how such findings can be integrated in reporting by both the anti-corruption and the human rights movements". ${ }^{7}$

In the words of the former UN Secretary General, Kofi Annan, corruption "undermines democracy and the rule of law, leads to violations of human rights, distorts markets, erodes the quality of life and allows organised crime, terrorism and other threats to human security to flourish". ${ }^{8}$ In more concrete terms, the UN High Commissioner for Human Rights referred to corruption as "an enormous obstacle to the realization of all human rights -civil, political, economic, social and cultural, as well as the right to development". According to him, "corruption denies access to justice for victims, exacerbates inequality, weakens governance and institutions, erodes public trust, fuels impunity and undermines the rule of law". ${ }^{9}$ These two statements summarize the main ways through which corruption impacts negatively on human rights, which have been confirmed by research in the last decade. ${ }^{10}$

Corruption may impact human rights indirectly, as an essential factor contributing to a chain of events that may hamper the protection of certain rights by, for example, deviating public funds from their original purposes. It may also affect human rights directly, constituting a violation of a specific human right. This occurs when a corrupt act is deliberately used as a means to violate a right, or when a State acts in a way that prevents individuals from enjoying that right or fails to act in a way that ensures that individuals can enjoy that right. ${ }^{11}$ This conceptualization of corruption as a violation of international human rights, which is more straight forward for petty corruption than for corruption on grand scale at transnational level, has been identified as beneficial and calls for mutual mainstreaming of international anti-corruption and human rights procedures. ${ }^{12}$

\footnotetext{
${ }^{7}$ Transparency International, Human Rights and Corruption”, Working Paper 05/2008.

${ }^{8}$ UN Secretary General, "Foreword", UN Convention against Corruption.

${ }^{9}$ United Nations High Commissioner for Human Rights, Report on the role of the public service as an essential component of good governance in the promotion and protection of human rights, 2013, para. 4.

${ }^{10}$ Op. Cit., note 6.

${ }^{11}$ UN Human Rights Council Advisory Committee, Final report of the on the issue of the negative impact of corruption on the enjoyment of human rights, 5 January 2015, A/HRC/28/73, para. 29.

${ }_{12}$ Peters, A., "Corruption as a Violation of International Human Rights", MPIL Research Paper Series, No. 2016-18.
} 
An illustrative example of how corruption may have a negative impact on human rights is its connection with human trafficking. Several studies have investigated the correlation between corruption and the prevalence of human trafficking showing positive results. ${ }^{13}$ Law enforcement officials (police, border control, immigration and customs officials) have been identified as the most likely to be involved in trafficking-related corruption, according to a survey run by UNODC. Corruption poses challenges for preventing, investigating and prosecuting trafficking crimes in various ways. ${ }^{14}$ It allows the crime of human trafficking to remain invisible, it facilitates impunity in some of the cases in which trafficking is detected, it facilitates trafficking circuits in the country and it increases the danger of re-victimisation for trafficking victims. ${ }^{15}$

The work of international institutions, NGOs and academics points out to mainly three ways in which corruption has a negative effect on human rights:

\section{i) Corruption has a negative impact on the right to equality}

The right to equality and non-discrimination, enshrined in many international and regional human rights instruments ${ }^{16}$ and usually formulated on grounds such as race, sex, language, religion and national or social origin, can be affected by corruption, both in the public and in the private sector, in various ways.

Corruption creates situations that may indirectly affect or directly violate the prohibition of discrimination. It frequently results in discriminatory access to public services and goods and renders those in vulnerable situations "more prone to adversely suffering from the negative social and environmental impacts of economic activities". ${ }^{17}$ If a public official accepts bribes to treat someone more favourably or to facilitate someone's access to a public service, ${ }^{18}$ the right

13 Zhang, S. X., Pineda, S. L., "Corruption as a Causal Factor in Human Trafficking”, in D. Siegel and H. Nelen, eds., Organized Crime: Culture, Markets and Policies, 2008; World Justice Project, WJP Rule of Law Index, 2014, 38; OECD, "Developing a Framework for Combatting Corruption Related to Trafficking in Persons", Background Paper, 2014, pp. 10-11.

${ }^{14}$ UNODC, "The Role of Corruption in Trafficking in Persons", Issue Paper, 2011.

15 International Bar Association, "Human Trafficking and Public Corruption. A Report by the IBA's Presidential Task Force Against Human Trafficking”, September 2016, p. 16.

16 Some of the most relevant instruments defining and protecting this right are the Charter of the United Nations (1945), the International Covenant on Civil and Political Rights (1966), the International Covenant on Economic, Social and Cultural Rights (1966), the International Convention on the Elimination of All Forms of Racial Discrimination (1965), the Convention on the Elimination of All Forms of Discrimination against Women (1979), the Declaration on the Elimination of All Forms of Intolerance and of Discrimination based on Religion or Belief (1981), the Declaration on the Rights of Persons Belonging to National or Ethnic, Religious and Linguistic Minorities (1992), the Inter-American Convention on the Elimination of All Forms of Discrimination against Persons with Disabilities (1999), the European Convention on Human Rights (1950), the European Social Charter (1961) and the revised European Social Charter (1996) and the EU Charter for Fundamental Rights (2000).

17 UN Human Rights Council, Resolution 35/25, The negative impact of corruption on the enjoyment of human rights, adopted on 23 June 2017.

${ }^{18}$ UN Human Rights Council Advisory Committee, Final report of the on the issue of the negative 
to equality and the prohibition of discrimination are affected, as this gives some people advantages that others don't have. ${ }^{19}$ This act of corruption distorts the normal functioning of the system and hampers equal access to opportunities and services. Basing the appointment to public office on political connections or payment of lump sums also hinders the right to equal treatment. ${ }^{20}$ The use of public funds by a public official for private benefits or for benefits of third parties is another example illustrating the negative effect of corruption on equality, as the consequence is allocating public resources to non-legitimate goals and ultimately diverting funds from their initially agreed use. UN human rights treaty bodies have identified corruption and mismanagement of resources as "obstacles to the allocation of resources to promote equal rights". ${ }^{21}$

The effect of corruption in equal opportunities can also be broader as shown in studies analysing the connection between corruption and inequality. Corruption may have as a consequence the transfer of resources from the mass public to elites ${ }^{22}$ and act as an extra tax on citizens, leaving less money for public expenditure and lowering economic growth. ${ }^{23}$ Furthermore, the most vulnerable groups of society are more affected by corruption as they are often more reliant on public services and public goods and have limited or no means to look for alternative private services. According to the $\mathrm{OHCHR}$, the poorest segments of the population are those who suffer the most from corruption, as they tend to be more vulnerable to bribe extortion and the amounts of bribes represent a higher share of their income. ${ }^{24}$

\section{ii) Corruption has a negative effect on access to justice}

Corruption can also be an obstacle for access to justice and may have a negative impact on the right to a fair trial and to an effective remedy. ${ }^{25}$ It can have direct damaging consequences on the functioning of the administration of justice, it can decrease public trust in justice, and it can weaken the capacity of judicial systems to guarantee the protection of human rights. ${ }^{26}$

impact of corruption on the enjoyment of human rights, 5 January 2015, A/HRC/28/73, para. 17

${ }^{19}$ Uslaner, E. M., Corruption, Inequality and the Rule of Law: The Bulging Pocket Makes the Easy Life, Cambridge University Press, 2008, p. 24.

${ }^{20}$ Kumar, C. R., Corruption and its Impact on Human Rights, in Corruption and Human Rights in India, OUP 2011, p. 41.

${ }^{21}$ Human Rights Treaty Bodies, Contributions to the 2030 Agenda for Sustainable Development, May 2016, p. 7.

22 Tanzi, V., "Corruption Around the World Causes, Consequences, Scope, and Cures", IMF Staff Papers Vol. 45, No. 4 (December 1998).

${ }^{23}$ Mauro, P., Why Worry about Corruption?, IMF, 1997.

24 Submission by OHCHR to the UN Human Rights Council Advisory Committee, 2013, The Negative Impact of Corruption on the Enjoyment of Human Rights.

${ }_{25}$ UN Human Rights Council, Resolution 35/25, The negative impact of corruption on the enjoyment of human rights, adopted on 23 June 2017.

26 UN Special Rapporteur on the Independence of Judges and Lawyers, Diego García-Sayán, 
According to the UN Special Rapporteur on the independence of judges and lawyers, judicial corruption undermines directly the rule of law and the ability of the judiciary to guarantee the protection of human rights. He also highlights that corruption can represent a very serious threat for judges, prosecutors, lawyers and other actors fighting against it and may directly or indirectly impede the proper discharge of their professional functions. ${ }^{27}$

Judicial corruption directly affects the right to a fair trial and the right to an effective remedy. ${ }^{28}$ It can undermine the guarantees of a fair trial impeding the administration of justice, if can affect the rights of the parties involved or distort the correct and efficient functioning of the procedure. This can happen for example when a judge delays a process to secure impunity by reaching timelimits in criminal cases. ${ }^{29}$ Bribery appears to be the most common practice, with examples of cases of speeding up or delaying a trial to benefit parties, biased rulings, recruitment, advancement, and job competitions. ${ }^{30}$

\section{iii) Corruption has a negative impact on other human rights}

Corruption also affects other human rights, directly or indirectly. The direct impact of corruption on certain rights, such as the right to housing or the right to education, may come from a situation in which a corrupt act prevents a person from having access to certain services, and may constitute a violation of human rights. ${ }^{31}$ Depending on the context in which corruption occurs, it can have a negative effect on many human rights at the same time. If public authorities illegally allow the deforestation of a land in return for a bribe, the right to food, the right to housing or the right to health of people living in the area may be affected. ${ }^{32}$

The indirect effect is broader in scope and affects the whole society. Corruption deprives societies of important resources that could be used for basic needs, such as public health, education, infrastructure or security. ${ }^{33}$ According to the OECD, the cost of corruption constitutes more than $5 \%$ of the global

Corruption, Human Rights and Judicial Independence, Doha Declaration, January 2018.

${ }^{27}$ Report of the UN Special Rapporteur on the independence of judges and lawyers to the UN Human Rights Council, Thirty-fifth session, A/HRC/35/31, June 2017, para 76.

${ }^{28}$ UN Human Rights Council Advisory Committee, Final report of the on the issue of the negative impact of corruption on the enjoyment of human rights, 5 January 2015, A/HRC/28/73, para. 19.

${ }^{29}$ Council of Europe Parliamentary Assembly, Committee on Legal Affairs and Human Rights Judicial Corruption: urgent need to implement the Assembly’s proposals, AS/Jur (2014) 19, 15 May 2014, p. 10.

30 Ibid, p. 8.

${ }^{31}$ Peters, A., "Corruption as a Violation of International Human Rights", MPIL Research Paper Series, No. 2016.

${ }^{32}$ UN Human Rights Council Advisory Committee, Final report of the on the issue of the negative impact of corruption on the enjoyment of human rights, 5 January 2015, A/HRC/28/73, p. 7.

${ }^{33}$ UN Special Rapporteur on the Independence of Judges and Lawyers, Diego García-Sayán, Corruption, Human Rights and Judicial Independence, Doha Declaration, January 2018. 
GDP. ${ }^{34}$ Corruption may divert funds away from social services and hinder the delivery of State services, preventing the realization of economic, social and cultural rights. ${ }^{35}$

Furthermore, corruption of the State and its institutions may hinder the full realization of civil, political, economic and social rights, which are all related to the exercise of the right to development. ${ }^{36}$ Financial and economic resources are affected by corruption, as corrupt practices may divert funds from development or services and interfere in the progressive realization of economic, social and cultural rights. ${ }^{37}$ Corruption can divert funds from State budgets that should be dedicated to the advancement of human rights, undermining States' obligation to maximize available resources for the progressive realization of rights recognized in article 2 of the International Covenant on Economic, Social and Cultural Rights. ${ }^{38}$

\section{b) Translating the substantive linkage into concrete measures: the perspective of the UN Human Rights Council}

The negative effects that corruption may have on human rights are, as mentioned above, generally acknowledged. What remains under consideration is what strategies should be used to translate that substantive linkage into concrete measures. ${ }^{39}$ The Office of the High Commissioner for Human Rights and the United Nations Office on Drugs and Crime are working together to identify the most effective strategies, pursuant to UN Human Rights Council Resolution 35/25.

This Resolution invites OHCHR and UNODC to "keep each other abreast of ongoing activities to deepen the understanding of the nexus between corruption and human rights" and encourages "cooperation between national anti-corruption authorities and national human-rights institutions, through the exchange of information, and the development of joint strategies and action plans to fight corruption and its negative effects on the enjoyment of human rights". As part of that joint effort, an Expert Workshop took place in June 2018 on good practices of United Nations-system support to States in preventing and fighting against corruption with a focus on human rights. The workshop

\footnotetext{
${ }^{34}$ CleanGovBiz (OECD), The rationale for fighting corruption, Background Brief, 2014.

35 Transparency International, "Human Rights and Corruption", Working Paper 05/2008.

${ }^{36}$ Kumar, C. R., Corruption and its Impact on Human Rights, in Corruption and Human Rights in India, OUP 2011, p. 63.

${ }^{37}$ UN Human Rights Council Advisory Committee, Final report of the on the issue of the negative impact of corruption on the enjoyment of human rights, 5 January 2015, A/HRC/28/73, p. 8 .

${ }_{38}$ Mauro, P., Why Worry about Corruption?, IMF, 1997. Submission by OHCHR to the UN Human Rights Council Advisory Committee, 2013, The Negative Impact of Corruption on the Enjoyment of Human Rights.

${ }^{39}$ UN Human Rights Council Advisory Committee, Final report of the on the issue of the negative impact of corruption on the enjoyment of human rights, 5 January 2015, A/HRC/28/73, para. 48.
} 
aimed at identifying opportunities for linking anti-corruption measures with the promotion and protection of human rights.

A close reading of $\mathrm{HRC}$ resolution 35/25 reveals the UN agenda in this respect and identifies the type of strategies to be explored for using that substantive link to define anti-corruption measures with positive effects on human rights. The areas identified coincide with areas of priority of the UNCAC, further analysed in section 3 .

\section{i. Prevention of corruption}

In that resolution, preventive measures are identified as one of the most effective means of avoiding the negative impact of corruption on the enjoyment of human rights. ${ }^{40}$ The UN Human Rights Council highlights that "States shall endeavour to establish and promote effective practices aimed at the prevention of corruption and its impact on the enjoyment of human rights, and to periodically evaluate relevant legal instruments and administrative measures with a view to determining their adequacy to prevent and fight corruption, including by ensuring transparency, access to public information, accountability, nondiscrimination and meaningful participation in the conduct of public affairs". ${ }^{41}$

\section{ii. International cooperation}

The Resolution underlines the necessity to "step up cooperation and coordination among different stakeholders at the national, regional and international levels to fight corruption in all its forms as a means of contributing positively to the promotion and protection of human rights". ${ }^{42}$ Paragraph 9 of the resolution stresses that international cooperation can "contribute to the prevention of the negative impact of corruption on the enjoyment of human rights, including through the delivery of advisory services, technical assistance and capacity-building, and the exchange of best practices to support States, upon their request, in their efforts in preventing and fighting against corruption".

The resolution underlines the importance of an independent and impartial judiciary, an independent legal profession, an objective and impartial prosecution and the integrity of the judicial system to prevent and combat corruption and to address its negative impact on human rights. It also emphasizes that States should "protect against any adverse human rights impacts arising from acts of corruption through effective regulatory and investigative mechanisms, with a view to holding perpetrators to account and providing redress to victims".

40 UN Human Rights Council, Resolution 35/25, The negative impact of corruption on the enjoyment of human rights, adopted on 23 June 2017, para 4.

${ }^{41}$ UN Human Rights Council, Resolution 35/25, op. cit., para 12.

${ }^{42}$ UN Human Rights Council, Resolution 35/25, op. cit., para 3. 
Connecting this resolution with the UNCAC, international cooperation should be explored in areas such as mutual legal assistance, extradition, prevention of corruption and judicial independence.

\section{iii. Recovering assets of illicit origin derived from acts of corruption}

The Resolution highlights the global character of corruption and the consequential need for international cooperation to prevent and suppress corruption and to recover assets of illicit origin derived from acts of corruption.

\section{iv. Protecting civil society and whistle-blowers}

The Resolution recognizes the importance of "creating a safe and enabling environment for civil society, whistle-blowers, witnesses, anti-corruption activists, journalists, prosecutors, lawyers and judges, and of protecting these individuals from any threats arising from their activities in preventing and fighting against corruption".

This human-rights look at anti-corruption strategies, which could materialize in diverse ways, has the potential to empower victims and move them to the centre of the fight against corruption, ${ }^{43}$ or at least to remind governments, legislators, policy makers, judges and civil society that corruption is not a victimless crime. ${ }^{44}$

\section{Cooperation against corruption between Latin-America and Europe under the UNCAC and its impact on human rights}

Given the substantive link between corruption and human rights, the UN Convention Against Corruption should be "considered as a fundamental international instrument for the protection of human rights" and should merit "the permanent attention of the bodies competent in this matter. ${ }^{45}$ As this monograph is dedicated to Euro-Latin-American cooperation on human rights, and international cooperation is one of the pillars of the UN Convention Against Corruption, this section looks at ways in which cooperation between European and Latin-American countries against corruption may have positive effects on human rights.

${ }^{43}$ UN Human Rights Council Advisory Committee, Final report of the on the issue of the negative impact of corruption on the enjoyment of human rights, 5 January 2015, A/HRC/28/73, p. 10.

${ }_{44}$ Peters, A., "Corruption as a Violation of International Human Rights", op. cit.

45 UN Special Rapporteur on the Independence of Judges and Lawyers, Diego García-Sayán, Corruption, Human Rights and Judicial Independence, Doha Declaration, January 2018. 
Looking at the areas identified by Resolution 35/25 of the UN Human Rights Council, it reflects on the potential positive effect of Euro-LatinAmerican cooperation against corruption on human rights in the following four areas: prevention of corruption (chapter II UNCAC), international cooperation initiatives under chapter IV of the Convention, repatriation of funds of illicit origin (chapter V UNCAC) and protection of whistle-blowers (chapter III UNCAC). It does it using examples of existing initiatives of cooperation against corruption between European and Latin-American countries which, while fighting against corruption, could have a positive effect on human rights.

\section{a) Prevention of corruption}

Cooperation at the inter-regional level could be instrumental for States to fulfil their commitments under chapter II of the $\mathrm{UNCAC}^{46}$ and to avoid the described devastating effects of corruption on human rights. The Conference of States Parties (COSP), in the Marrakech declaration on prevention of corruption, ${ }^{47}$ requested Member States to promote bilateral, regional and international activities to prevent corruption, including workshops for the exchange of relevant experiences and good practices. ${ }^{48}$ More recently, in its Resolution 7/5, it called the UNODC Secretariat and multilateral, regional and bilateral assistance providers to "continue recognizing the importance of cooperation, to provide technical assistance to States parties and to contemplate tailored assistance for participation in the review process for implementation of chapter II", which is now ongoing ${ }^{49}$ as part of the second cycle of the Mechanism for the Review of Implementation of the UNCAC.

The same resolution called upon States parties to ensure that anti-corruption bodies have the "necessary independence and competence, as well as the

${ }^{46}$ Chapter II of the UNCAC contains provisions on preventive anti-corruption policies, practices and bodies, prevention of corruption in the public sector, codes of conduct, public procurement and finances, integrity and independence of the judiciary and active participation of civil society and individuals in the public sector.

${ }^{47}$ Conference of the States Parties to the United Nations Convention against Corruption, Resolution 4/3 "Marrakech declaration on the prevention of corruption" of 28 October 2011.

${ }^{48}$ Resolution 5/4 of the COSP in 2013 (Conference of the States Parties to the United Nations Convention against Corruption, Resolution 5/4 "Follow-Up to The Marrakech Declaration on The Prevention of Corruption", adopted at its fifth session, held in Panama City, Panama, from 25 to 29 November 2013) decided that the Open-ended Intergovernmental Working Group on the Prevention of Corruption, set up by Resolution $3 / 2$ of 13 November 2009, shall continue its work to advise and assist the Conference in the implementation of its mandate on the prevention of corruption and recognized the role of the Group in facilitating the sharing between States parties of information on their initiatives and good practices on the topics considered. The outcome of recent meetings of the Working Group is accessible here: http://www.undocs.org/CAC/COSP/WG.4/2017/4 and http://www. undocs.org/CAC/COSP/WG.4/2016/5.

${ }^{49}$ Conference of the States Parties to the United Nations Convention against Corruption, Resolution $7 / 5$ "Promoting preventive measures against corruption", adopted in its $7^{\text {th }}$ Session in Vienna, from 6 to 10 November 2017, para 13.

Araucaria. Revista Iberoamericana de Filosofia, Politica, Humanidades y Relaciones Internacionales, año 20, $\mathrm{n}^{\circ} 40$ Segundo semestre de 2018. Pp. 605-629. ISSN 1575-6823 e-ISSN 2340-2199 doi: 10.12795/araucaria.2018.i40.25 
material resources, specialized staff and training, to carry out their functions effectively and free from undue influence". ${ }^{50}$ It also encouraged States parties to promote transparency and prevent conflicts of interest, to use innovative and digital instruments, ${ }^{51}$ and to prevent opportunities for corruption among the judiciary through initiatives like the Global Judicial Integrity Network. It also encouraged State parties to "raise public awareness regarding the existence, causes and gravity of and the threat posed by corruption". ${ }^{52}$

Within these areas, judicial integrity and awareness raising particularly show potential for European and Latin-American countries to cooperate against corruption with a positive effect on human rights. On judicial integrity, the recently launched Global Judicial Integrity Network ${ }^{53}$ aims to assist judiciaries across the globe in strengthening judicial integrity and preventing corruption in the justice sector, in line with article 11 of the UNCAC. Although this initiative launched by the UN Office on Drugs and Crime with the financial support of the State of Qatar is limited in time (four years), it could contribute to consolidate long-term cooperation initiatives at the global level.

The Network, at which many European and Latin-American States take part, is a platform for judges to share good practices and lessons learned, to support each other, and to join forces in developing new tools and guidelines for strengthening integrity and preventing corruption in the judicial system. It will do so by organising training programmes and events, as well as providing access to a large online database featuring resources, good practices, and other judicial documents. ${ }^{54}$ Its first workshop, organized in partnership with the European Judicial Training Network (EJTN) and the Judicial College of England and Wales, focused on how to develop and design national and regional judicial ethics training activities, in line with the Judicial Ethics Training Tools currently being developed by UNODC. Only Brazil took part from the LatinAmerican Region and Europe was present only through the organizers. The low participation of countries from the two observed regions in this workshop is not a promising sign but may just be an indicator of the early stages at which this project is.

The participation of European and Latin-American countries in the Network could have great potential for the benefit of human rights. This

\footnotetext{
${ }^{50}$ Para 4.

51 Para 9.

52 Para 12.

53 It was launched in April 2018 following the Doha declaration on integrating crime prevention and criminal justice into the wider united nations agenda to address social and economic challenges and to promote the rule of law at the national and international levels, and public participation. 13th UN Congress on Crime Prevention and Criminal Justice, Doha, 12-19 April 2015.

${ }^{54}$ Chief Justices and senior judges launch UNODC's Global Judicial Integrity Network, available here: https://www.unodc.org/dohadeclaration/en/news/2018/04/chief-justices-and-senior-judgeslaunch-unodes-global-judicial-integrity-network.html
} 
involvement would provide them guidance and technical assistance on how to adapt that guidance to existing domestic judicial ethics regulations, which remains a challenge in many cases. This would empower the judiciary and would contribute to a more transparent and fair functioning of the judiciary preventing judicial corruption. That would have a positive effect on human rights, as courts would be better able to protect human rights through their judgements and the rights that are directly linked to the administration of justice would be better protected.

On awareness raising, education in schools and universities on anticorruption efforts (article 13.1.c UNCAC) is an area where many European and Latin-American countries are developing promising practices. Cooperation and experience sharing among those countries at the inter-regional level could be beneficial for human rights as it would contribute to systematizing anticorruption education in schools and universities. Some examples reported to the Open-ended Intergovernmental Working Group on Prevention of Corruption are the following. ${ }^{55}$ Austria, Germany, Greece, Norway, Slovakia and Slovenia reported that corruption is addressed in schools. Slovenia added that since anti-corruption was a difficult topic for teachers to address, the country's anticorruption body developed lessons on corruption which teachers could deliver within classes on citizenship education and sociology. In Austria, the Federal Anti-Corruption Bureau offered extracurricular anti-corruption lectures and programmes in schools' programmes upon schools' request.

In Ecuador, under the transparency Brigades Programme, university students worked with local authorities to assess the level of transparency in public services. Those students monitored and promoted compliance with access to information laws, conducted research and made proposals on transparency and ethical behaviour in public bodies, and helped to create a corruption risk map for local authorities. The Regional Anti-Corruption Academy for Central America and the Caribbean delivered courses on corruption in various universities in Panama. In Brazil, the national strategy to combat corruption and money-laundering was discussing the creation of a certificate on primary prevention of corruption to be issued to schools and public institutions that worked successfully to prevent corruption. ${ }^{56}$ The Interamerican Development Bank supports the creation of a virtual course that allows to increase the teachers' capacities to teach values of integrity, transparency and legality, and to prevent corruption through better civic education of future citizens of the region. ${ }^{57}$

${ }^{55}$ Open-ended Intergovernmental Working Group on the Prevention of Corruption, Education in schools and universities on anti-corruption efforts (article 13, paragraph 1 (c) of the United Nations Convention against Corruption), Background paper prepared by the Secretariat, 28 May 2017, CAC/ COSP/WG.4/2017/2/Rev.1.

${ }^{56}$ Ibid.

${ }^{57}$ Project supported through its Institutional Capacity of the State Division (IFD/ICS), and with the collaboration of the Organization of the American States (OAS), through its Education and Culture 
Many of these countries referred to challenges and technical assistance needs on anti-corruption education, such as the Czech Republic, Slovakia, Brazil or Ecuador. This call for assistance is an indication of the positive effect that cooperation could have in this area. It would empower governments in their efforts to prevent corruption through education at school. It would also empower students as active citizens who will be more likely to avoid corrupt acts in their professional life and to engage with civil society organisations who tackle corruption. Educating future citizens in the values of integrity, citizenship, transparency and prevention of corruption results in adult citizens who are less permissive of corrupt practices and less likely to violate the law. ${ }^{58}$

\section{b) International cooperation under chapter IV of the UNCAC}

As mentioned above, paragraph 9 of Resolution 35/25 of the UN Human Rights Council stresses that international "cooperation can contribute to the prevention of the negative impact of corruption on the enjoyment of human rights, including through the delivery of advisory services, technical assistance and capacity-building, and the exchange of best practices to support States, upon their request, in their efforts in preventing and fighting against corruption".

Chapter IV of the UN Convention Against Corruption focuses on international cooperation and contains specific provisions on international cooperation for extradition, transfer of sentenced persons, mutual legal assistance, transfer of criminal proceedings, law enforcement cooperation, joint investigations and special investigative techniques. Under its article 44, States Parties "shall cooperate in criminal matters and shall consider assisting each other in investigations of and proceedings in civil and administrative matters relating to corruption, where appropriate and consistent with their domestic legal system". ${ }^{9}$

The first cycle of the review implementation mechanism showed generally a solid implementation of this part of the Convention, mainly because many countries can apply the text of the Convention directly and they have accumulated experience cooperating internationally in other areas. However,

\footnotetext{
Office and the Education Portal of the Americas (PEA).

${ }^{58}$ Research developed by the International Association for the Evaluation of Educational Achievement (IEA) showed that, for a selected group of Latin-American countries, lower secondary students who have received this kind of education are less permissive of corrupt practices and less likely to violate the law (W. Schulz, C. Cox, J. Ainley, T. Friedman, "Young People's Views of Government, Peaceful Coexistence, and Diversity in Five Latin-American Countries", IEA International Civic and Citizenship Education Study 2016 Latin-American Report, 2018).

${ }^{59}$ It also provides that, when dual criminality is required for international cooperation purposes, it shall be deemed fulfilled irrespective of whether the laws of the requested State Party place the offence within the same category of offence or denominate the offence by the same terminology as the requesting State Party, if the conduct underlying the offence for which assistance is sought is a criminal offence under the laws of both States Parties.
} 
implementation still faces several operational challenges, mainly related to limited resources or "technical expertise available to use videoconferencing for mutual legal assistance purposes or to carry out special investigative techniques, either domestically or in the execution of foreign requests". ${ }^{60}$

Cooperation to overcome these challenges would greatly benefit the States involved. The Conference of States Parties has recommended States to consider the" allocation of adequate resources to further strengthen the efficiency and capacity of international cooperation mechanisms and identified as promising certain practices of States Parties using technology and electronic databases in an efficient way to track, monitor and follow up on international cooperation requests". Also identified as good practices were "active participation in international and regional networks, platforms and forums aimed at promoting international cooperation", and "provision of training to practitioners, in particular law enforcement and judicial officers, regarding applicable laws, procedures and time frames to be followed in international cooperation cases, including the determination of dual criminality". ${ }^{61}$ Some of the promising Euro-Latin-American initiatives presented below could contribute to overcome those challenges. ${ }^{62}$

Judicial cooperation and mutual legal assistance is not new between European and Latin-American countries. The fact that several Latin-American countries have signed the Council of Europe Convention on the Transfer of Sentenced Persons ${ }^{63}$ or the cooperation that has been ongoing for years on mutual legal assistance ${ }^{64}$ are signs of decades of good cooperation. Also interesting is the cooperation agreement between the Conference of Ministers of Justice of Ibero-American Countries (COMJIB) and the International Police Organization (INTERPOL), signed in October 2012 to promote judicial and police cooperation at the national, regional and international levels. However, strengthening such cooperation to overcome the challenges to tackle corruption with a human rights approach would be greatly beneficial for human rights.

${ }^{60}$ COSP, Summary of the state of implementation of the United Nations Convention against Corruption: criminalization, law enforcement and international cooperation, CAC/COSP/2017/10, paras. 6 and 7 .

${ }^{61}$ COSP, Set of non-binding recommendations and conclusions based on lessons learned regarding the implementation of chapters III and IV of the Convention, in line with Conference resolution 6/1, para. 11, CACC/COPS/2017/5, p. 8.

${ }^{62}$ Vlasis, D., Issues Concerning the Implementation of the UN Convention Against Corruption, the $14^{\text {th }}$ UNAFEI UNCAC Training Programme Visiting Experts' Papers, Resource Material Series No. 86 .

63 UNODC, State of implementation of the United Nations Convention against Corruption Criminalization, law enforcement and international cooperation Second edition, 2017, p. 266.

${ }^{64}$ European Commission, DG Justice, Study on judicial cooperation, mutual legal assistance and extradition of drug traffickers and other drug-related crime offenders, between the EU and its Member States and Latin-American and Caribbean (LAC) countries, 2013.

Araucaria. Revista Iberoamericana de Filosofia, Política, Humanidades y Relaciones Internacionales, año 20, $\mathrm{n}^{\circ} 40$ Segundo semestre de 2018. Pp. 605-629. ISSN 1575-6823 e-ISSN 2340-2199 doi: 10.12795/araucaria.2018.i40.25 
A promising example of Euro-Latin-American cooperation against corruption is the Ibero-American Legal Assistance Network (IberoRed) and its cooperation with the European Judicial Network. It is common practice for judges to ask for additional information to avoid a request for extradition or surrender being refused. ${ }^{65}$ Another promising initiative is the cooperation that occurs within the Financial Action Task Force, inter-governmental body established in 1989 by the Ministers of its Member jurisdictions. The objectives of the FATF, with European and Latin-American countries within its membership, ${ }^{66}$ are to set standards and promote effective implementation of legal, regulatory and operational measures for combating money laundering, terrorism financing and other related threats to the integrity of the international financial system.

Another area where cooperation is promising is the use of technology, with the Ibero-American Convention on the Use of Videoconferencing in International Cooperation between Judicial Systems signed in Mexico in 2010. This is important as the use of electronic tools and systems has been encouraged by the fifth open-ended intergovernmental expert meeting to enhance international cooperation, for processing and tracking extradition and mutual legal assistance requests. ${ }^{67}$

Furthermore, revising implementation of chapter IV of the UNCAC, the COSP considered the European Arrest Warrant (2002) as a promising step forward, as it replaced extradition procedures among European Union member States by de facto eliminating political control over the surrender procedure for a significant number of offences, including corruption-related ones. In addition, under the European Arrest Warrant, ${ }^{68}$ the dual criminality principle was removed in relation to a list of 32 offences, including corruption related offences punishable in the issuing member State by custodial sentence or a detention order for a maximum period of at least three years and as they are defined by the law of the issuing member State.$^{69}$ Latin-American countries of civil-law tradition showed a tendency to regulate extradition and mutual legal

${ }^{65}$ UNODC, State of implementation of the United Nations Convention against Corruption Criminalization, law enforcement and international cooperation Second edition, 2017, p. 217-218.

${ }^{66}$ Argentina, Austria, Belgium, Brazil, Denmark, European Commission, Finland, France, Germany, Greece, Ireland, Italy, Luxembourg, Mexico, Netherlands, Norway, Portugal, Spain, Sweden, Switzerland, United Kingdom are some of its members, and the Financial Action Task Force of Latin-America (GAFILAT) is an associate member. Members of GAFILAT are: Argentina, Bolivia, Brazil, Chile, Colombia, Costa Rica, Cuba, Dominican Republic, Ecuador, Guatemala, Honduras, Mexico, Nicaragua, Panama, Paraguay, Peru, Uruguay. Some European countries are observer jurisdictions to GAFILAT: France, Germany, Portugal, Spain.

${ }^{67} \mathrm{COSP}$, Conference paper on data collection and effective case management systems, CAC/ COSP/EG.1/2017/CRP. 1

${ }^{68}$ Reuters, Latin-American prosecutors join forces on Odebrecht bribes, February 2017.

69 UNODC, State of implementation of the United Nations Convention against Corruption Criminalization, law enforcement and international cooperation, Second edition, 2017, p. 267.

Araucaria. Revista Iberoamericana de Filosofía, Política, Humanidades y Relaciones Internacionales, año 20, ${ }^{\circ} 40$. Segundo semestre de 2018. Pp. 605-629. ISSN 1575-6823 e-ISSN 2340-2199 doi: 10.12795/araucaria.2018.i40.25 
assistance matters through scattered provisions in their constitutions, criminal codes and criminal procedure codes. ${ }^{70}$

Inter-regional cooperation in this regard could contribute to the consideration of a similar mechanism in Latin-America, where prosecutors are joining forces to overcome the challenges of cross-border corruption cases. ${ }^{71}$ The positive effect of this cooperation on human rights would come from the better functioning of the judicial mechanisms to prosecute those who commit acts of corruption and the subsequent better protection of victims.

\section{c) Repatriation of funds of illicit origin to the countries of origin}

The UN Human Rights Council has acknowledged that "flows of funds of illicit origin deprive countries of resources required to progressively realize human rights, including economic, social and cultural rights, and in particular the right to development, in such a way that threatens the stability and sustainable development of States, undermines the values of democracy, the rule of law and morality and jeopardizes social, economic and political development". ${ }^{72}$ The UN General Assembly has also called for "greater international cooperation and sustained dialogue to combat illicit financial flows and strengthen good practices on assets return to foster sustainable development". ${ }^{73}$

Although corruption-based illicit financial outflows account only for a small fraction of all illicit financial flows, the international asset recovery efforts relating to corruption-based illicit financial flows are still far from ideal, as reported in 2014 by the joint initiative of the World Bank, UNODC and OECD Stolen Asset Recovery Initiative (StAR).$^{74}$ Return of assets is one of the fundamental principles of the Convention, which aims, among other goals, at facilitating the return of the proceeds of corruption-related crimes. Under chapters IV and V of the Convention, the requesting and requested States have a duty to cooperate and to provide mutual assistance leading to facilitating the return of illicit assets.

However, authorities in the requesting and the requested States face challenges and difficulties in the return of proceedings of corruption, "due to differences in legal systems, the complexity of multijurisdictional investigations

\footnotetext{
${ }^{70}$ Ibid., p. 266.

${ }^{71}$ Reuters, Latin-American prosecutors join forces on Odebrecht bribes, February 2017.

${ }^{72}$ UN Human Rights Council, Resolution 34/11 "The negative impact of the non-repatriation of funds of illicit origin to the countries of origin on the enjoyment of human rights, and the importance of improving international cooperation”, adopted on 23 March 2017.

73 UNGA Resolution, Promotion of international cooperation to combat illicit financial flows in order to foster sustainable development, adopted on 20 December 2017A/RES/72/207, para 12.

${ }^{74}$ Gray, L., Hansen, K., Recica-Kirkbride, P., Mills, L., Few and Far. The Hard Facts on Stolen Asset Recovery, International Bank for Reconstruction and Development/The World Bank, OECD, 2014.
} 
and prosecutions, the lack of familiarity with the mutual legal assistance procedures of other States and difficulties in identifying the flow of funds of illicit origins". ${ }^{75}$ To overcome those difficulties, the UN Human Rights Council has urged requesting and requested States to "cooperate to recover the proceeds of corruption, in particular embezzled public funds, stolen assets and unaccountedfor assets, including those that are found in safe havens" ${ }^{76}$ It encourages requested State parties to "respond to requests for assistance and to consider adopting necessary measures to enable them to provide a wider scope of assistance in the absence of dual criminality" (46 UNCAC) and "calls for close cooperation at the national and international levels between anti-corruption agencies, law enforcement agencies and financial intelligence units in support of national, sub regional and regional efforts to prevent and combat corrupt practices and the transfer of assets of illicit origin, in accordance with the principles of the UNCAC', 77

States have been called to make every effort to achieve the repatriation of funds of illicit origin to diminish the negative impact of non-reparation, including on the enjoyment of human rights. ${ }^{78}$ In that attempt, given the complex technical issues that repatriation of this kind of funds may raise, experience has been identified as a tool and States with practical experience in asset recovery as potential role models and providers of technical assistance. ${ }^{79}$

The most promising international cooperation initiative of which European and Latin-American countries are taking part is StAR, the Stolen Assets Recovery Initiative, which supports efforts of policymakers and practitioners to return stolen assets, remove barriers to asset recovery, and prevent laundering of proceeds of corruption. It also generates a public database that tracks efforts by prosecution authorities worldwide to go after assets that stem from corruption. Under the StAR initiative, countries assist mutually and provide each other technical assistance on asset recovery-related issues. ${ }^{80}$

Cooperation in this area will result in higher levels of repatriation of funds of illicit origin, which could have a positive effect on human rights. However, this positive effect will depend on the use given to those funds. A human rights approach would, as already mentioned, put victims at the centre. If the corruption case has a clearly identified victim, the repatriated funds could be used to compensate victims. If not, they could be used to compensate local communities or parts of the society particularly affected by the corruption act

${ }^{75}$ UN Human Rights Council, Resolution 34/11 "The negative impact of the non-repatriation of funds of illicit origin to the countries of origin on the enjoyment of human rights, and the importance of improving international cooperation", adopted on 23 March 2017.

76 Ibid., para. 5.

77 Ibid., para 21.

78 Ibid., para 22.

79 Ibid., para 26.

${ }^{80}$ More information available here: https://star.worldbank.org/. 
in question or by corruption in general. Countries like Italy or Colombia have interesting experiences to share in relation to social reuse of repatriated assets of illicit origin which could be worth sharing as experience for others. ${ }^{81}$

\section{d) Protection of whistle-blowers}

As already mentioned, Resolution 35/25 of the UN Human Rights Council recognizes the importance of "creating a safe and enabling environment for civil society, whistle-blowers, witnesses, anti-corruption activists, journalists, prosecutors, lawyers and judges, and of protecting these individuals from any threats arising from their activities in preventing and combatting corruption". ${ }^{82}$ The role that civil society can play in exposing corruption and drawing attention to the negative impact of the non-repatriation of funds of illicit origin in the realization of economic, social and cultural rights has been acknowledged and has led the UN relevant bodies to remind States of their obligation to protect reporting persons in accordance with article 33 of the UNCAC. ${ }^{83}$

The EU Directive recently proposed by the European Commission to protect whistle-blowers could be a step forward in this direction and could become a leading example for other regions as Latin-America. After a first unsuccessful attempt to pass a European bill protecting whistle-blowers and with the 2014 Recommendation of the Council of Europe as the only precedent, ${ }^{84}$ the European Commission proposed on 23 April 2018 a Directive on the protection of persons reporting on breaches of Union law. ${ }^{85}$ The lack of effective protection of whistle-blowers has raised growing concerns as regards its negative impacts on freedom of expression (art. 11 EU Charter of Fundamental Rights) and has led civil society organisations to call for an EU-wide legislation protecting them, acting in the public interest. ${ }^{86}$ The proposed directive aims at increasing

${ }^{81}$ UNODC, Effective management and disposal of seized and confiscated assets, 2017, pp. 38-42.

${ }^{82}$ UN Human Rights Council, Resolution 35/25, The negative impact of corruption on the enjoyment of human rights, adopted on 23 June 2017.

${ }^{83}$ UN Human Rights Council, Resolution 34/11 "The negative impact of the non-repatriation of funds of illicit origin to the countries of origin on the enjoyment of human rights, and the importance of improving international cooperation", adopted on 23 March 2017, para 18 and UN Human Rights Council, Summary report of the Human Rights Council panel discussion on the negative impact of corruption on the enjoyment of human rights, 18 April 2013, A/HRC/23/26, paras. 14, 18 and 19. Article 33 of the United Nations Convention against Corruption commits signatories to implement appropriate legislation to ensure and promote the disclosure of information as well as to provide protection for whistle-blowers.

${ }^{84}$ Recommendation CM/Rec (2014)7 of the Committee of Ministers to member States on the protection of whistle-blowers (Adopted by the Committee of Ministers on 30 April 2014, at the 1198th meeting of the Ministers' Deputies)

${ }^{85}$ Proposal for a Directive of the European Parliament and of the Council on the protection of persons reporting on breaches of Union law, Brussels, 23.4.2018 COM (2018) 218 final.

${ }^{86}$ European Commission, Staff Working Document, Impact Assessment Accompanying the document Proposal for a Directive of the European Parliament and of the Council on the protection of persons reporting on breaches of Union law, Brussels, 23.4.2018 SWD (2018) 116 final.

Araucaria. Revista Iberoamericana de Filosofia, Política, Humanidades y Relaciones Internacionales, año 20, $\mathrm{n}^{\circ} 40$ Segundo semestre de 2018. Pp. 605-629. ISSN 1575-6823 e-ISSN 2340-2199 doi: 10.12795/araucaria.2018.i40.25 
the detection and prevention of breaches as, according to the 2017 Special Eurobarometer on corruption, $81 \%$ of Europeans indicated that they did not report corruption that they experienced or witnessed. ${ }^{87}$

If adopted, this Directive would prohibit any form of retaliation and would oblige States to adopt measures to protect whistle-blowers against retaliation. ${ }^{88}$ Although the process to its adoption may be long and challenging, this promising initiative could serve as inspiration in Latin-America where some countries recently adopted national legislation protecting whistle-blowers but where this protection is still, as in Europe, uneven. ${ }^{89}$

Sharing their experiences and discussing common challenges, European and Latin-American countries could better legislate and enforce the legislation protecting whistle-blowers, ensuring that retaliation is prohibited, and that protections and incentives are accessible. Such protection would translate into more transparent investigations, a better protection of the rights of whistleblowers and ultimately less cases of corruption. That would have a positive effect on human rights, not only on the human rights of the whistle-blowers protected but also, more broadly, on the human rights of members of that society, which would be better off without corruption.

\section{Conclusions}

Corruption has a negative effect on human rights, which can be direct or indirect. In some cases, corruption constitutes a violation of human rights. In other cases, it may not constitute a violation of a right, but it may create circumstances that hamper human rights. This negative effect manifests in its impact on the right to equality, on access to justice and on other human rights, including the right to development.

The UN Human Rights Council has identified various areas in which there is potential to unfold the substantive link between corruption and human rights for impacting human rights positively by combatting corruption. Some of those areas are: prevention of corruption, international cooperation under article IV of the UNCAC, repatriation of funds of illicit origin and protection of whistleblowers.

Euro-Latin-American cooperation has been ongoing for decades in many areas including corruption. European and Latin-American countries take part in initiatives like the Global Judicial Integrity Network or the Stolen Assets Recovery Initiative (StAR), and such cooperation could be beneficial for

\footnotetext{
${ }^{87}$ Special Eurobarometer on Corruption, 2017.

${ }^{88}$ Proposal for a Directive of the European Parliament and of the Council on the protection of persons reporting on breaches of Union law, Brussels, 23.4.2018 COM (2018) 218 final.

${ }^{89}$ Mexico, Argentina and Brazil have recently adopted legislation protecting whistle-blowers.
} 
human rights, as explained in this paper. Therefore, this cooperation should be strengthened and continued in order to identify the most effective avenues to better protect human rights by tackling corruption. The upcoming meetings under the auspices of the UNODC and the UN Human Rights Council will be key to evaluate the progress made and to design the route map for the years. Sharing promising practices on education against corruption and on judicial ethics are just two illustrative examples showing the potential of such cooperation. 


\section{References}

\section{Academic references and non-UN institutional studies}

Boersma, M., Corruption: A Violation of Human Rights and a Crime Under International Law, Intersentia, 2012.

CleanGovBiz (OECD), The rationale for fighting corruption, Background Brief, 2014.

Council of Europe Parliamentary Assembly, Committee on Legal Affairs and Human Rights Judicial Corruption: urgent need to implement the Assembly's proposals, AS/Jur (2014) 19, 15 May 2014.

European Commission, DG Justice, Study on judicial cooperation, mutual legal assistance and extradition of drug traffickers and other drug-related crime offenders, between the EU and its Member States and Latin-American and Caribbean (LAC) countries, 2013.

European Commission, Staff Working Document, Impact Assessment Accompanying the document Proposal for a Directive of the European Parliament and of the Council on the protection of persons reporting on breaches of Union law, Brussels, 23.4.2018 SWD (2018) 116 final.

Gray, L., Hansen, K., Recica-Kirkbride, P., Mills, L., Few and Far. The Hard Facts on Stolen Asset Recovery, International Bank for Reconstruction and Development/The World Bank, OECD, 2014.

International Bar Association, "Human Trafficking and Public Corruption. A Report by the IBA's Presidential Task Force Against Human Trafficking", September 2016.

Kaufmann, D., Human Rights and Governance: The Empirical Challenge, in Human Rights and Development: Towards Mutual Reinforcement, edited by Philip Alston and Mary Robinson, Oxford University Press, 2005.

Kumar, C. R., Corruption and its Impact on Human Rights, in Corruption and Human Rights in India, OUP, 2011.

Landman, T., Schudel, C. J. W., Corruption and Human Rights: Empirical Relationships and Policy Advice, International Council on Human Rights Policy, 2007.

Mauro, P., Why Worry about Corruption?, IMF, 1997.

OECD, "Developing a Framework for Combatting Corruption Related to Trafficking in Persons", Background Paper, 2014, pp. 10-11.

Peters, A., "Corruption as a Violation of International Human Rights", MPIL Research Paper Series, No. 2016-18.

Proposal for a Directive of the European Parliament and of the Council on the protection of persons reporting on breaches of Union law, Brussels, 23.4.2018 COM (2018) 218 final. 
Recommendation CM/Rec (2014)7 of the Committee of Ministers to member States on the protection of whistle-blowers (Adopted by the Committee of Ministers on 30 April 2014, at the 1198th meeting of the Ministers' Deputies).

Reuters, Latin-American prosecutors join forces on Odebrecht bribes, February 2017.

Special Eurobarometer on Corruption, 2017.

Tanzi, V., "Corruption Around the World Causes, Consequences, Scope, and Cures", IMF Staff Papers Vol. 45, No. 4 (December 1998).

Transparency International, "Human Rights and Corruption", Working Paper $05 / 2008$.

Uslaner, E. M., Corruption, Inequality and the Rule of Law: The Bulging Pocket Makes the Easy Life, Cambridge University Press, 2008.

W. Schulz, C. Cox, J. Ainley, T. Friedman, "Young People's Views of Government, Peaceful Coexistence, and Diversity in Five Latin-American Countries", IEA International Civic and Citizenship Education Study 2016 Latin-American Report, 2018.

World Justice Project, WJP Rule of Law Index, 2014, 38.

Zhang, S. X., Pineda, S. L., "Corruption as a Causal Factor in Human Trafficking”, in D. Siegel and H. Nelen, eds., Organized Crime: Culture, Markets and Policies, 2008.

\section{UN references}

UNGA Resolution, Promotion of international cooperation to combat illicit financial flows in order to foster sustainable development, adopted on 20 December 2017A/RES/72/207.

UN Human Rights Council, Resolution 35/25, The negative impact of corruption on the enjoyment of human rights, adopted on 23 June 2017.

UN Secretary General, "Foreword", UN Convention against Corruption.

United Nations High Commissioner for Human Rights, Report on the role of the public service as an essential component of good governance in the promotion and protection of human rights, 2013.

UN Human Rights Council Advisory Committee, Final report of the on the issue of the negative impact of corruption on the enjoyment of human rights, 5 January 2015, A/HRC/28/73.

UNODC, "The Role of Corruption in Trafficking in Persons", Issue Paper, 2011.

Human Rights Treaty Bodies, Contributions to the 2030 Agenda for Sustainable Development, May 2016. 
Submission by OHCHR to the UN Human Rights Council Advisory Committee, The Negative Impact of Corruption on the Enjoyment of Human Rights, 2013.

Report of the UN Special Rapporteur on the independence of judges and lawyers to the UN Human Rights Council, Thirty-fifth session, A/HRC/35/31, June 2017.

Resolution 5/4 of the COSP in 2013 (Conference of the States Parties to the United Nations Convention against Corruption, Resolution 5/4 "FollowUp to The Marrakech Declaration on The Prevention of Corruption", adopted at its fifth session, held in Panama City, Panama, from 25 to 29 November 2013

Conference of the States Parties to the United Nations Convention against Corruption, Resolution 7/5 "Promoting preventive measures against corruption", adopted in its $7^{\text {th }}$ Session in Vienna, from 6 to 10 November 2017.

Open-ended Intergovernmental Working Group on the Prevention of Corruption, Education in schools and universities on anti-corruption efforts (article 13, paragraph 1 (c) of the United Nations Convention against Corruption), Background paper prepared by the Secretariat, 28 May 2017, CAC/COSP/ WG.4/2017/2/Rev.1.

COSP, Summary of the state of implementation of the United Nations Convention against Corruption: criminalization, law enforcement and international cooperation, CAC/COSP/2017/10.

Vlasis, D., "Issues Concerning the Implementation of the UN Convention Against Corruption", the $14^{\text {th }}$ UNAFEI UNCAC Training Programme Visiting Experts' Papers, Resource Material Series No. 86.

COSP, Set of non-binding recommendations and conclusions based on lessons learned regarding the implementation of chapters III and IV of the Convention, in line with Conference resolution 6/1, para. 11, CACC/ COPS/2017/5.

COSP, Agenda and annotations on meeting of experts convened to enhance international cooperation under the United Nations Convention against Corruption in Nov 2017, CAC/COSP/EG.1/2017/1.

UNODC, State of implementation of the United Nations Convention against Corruption Criminalization, law enforcement and international cooperation, Second edition, 2017.

COSP, Conference paper on data collection and effective case management systems, CAC/COSP/EG.1/2017/CRP.1. 
UN Human Rights Council, Resolution 34/11 "The negative impact of the non-repatriation of funds of illicit origin to the countries of origin on the enjoyment of human rights, and the importance of improving international cooperation", adopted on 23 March 2017.

UN Human Rights Council, Illicit financial flows, human rights and the post2015 development agenda, Interim study by the Independent Expert on the effects of foreign debt and other related international financial obligations of States on the full enjoyment of all human rights, particularly economic, social and cultural rights, Juan Pablo Bohoslavsky, 10 February 2015, A/ $\mathrm{HRC} / 28 / 60$.

UNODC, Effective management and disposal of seized and confiscated assets, 2017. 
